\title{
BMJ Open Dietary determinants of serum total cholesterol among middle-aged and older adults: a population-based cross- sectional study in Dar es Salaam, Tanzania
}

\author{
Sujay S Kakarmath, ${ }^{1}$ Rachel M Zack, ${ }^{2}$ Germana H Leyna, ${ }^{3}$ Saman Fahimi, ${ }^{1}$ \\ Enju Liu, ${ }^{1}$ Wafaie W Fawzi, ${ }^{1,2,4}$ Zohra Lukmanji, ${ }^{5}$ Japhet Killewo, ${ }^{3}$ Frank Sacks, ${ }^{4}$ \\ Goodarz Danaei ${ }^{1,2}$
}

To cite: Kakarmath SS, Zack RM, Leyna GH, et al. Dietary determinants of serum total cholesterol among middle-aged and older adults: a population-based crosssectional study in Dar es Salaam,

Tanzania. BMJ Open 2017;7:e015028. doi:10.1136/ bmjopen-2016-015028

- Prepublication history and additional material are available. To view these files please visit the journal online (http://dx.doi.org/ 10.1136/ bmjopen-2016-015028).

Received 3 November 2016 Revised 27 February 2017 Accepted 5 April 2017

CrossMark

For numbered affiliations see end of article.

Correspondence to

Dr. Goodarz Danaei; gdanaei@hsph.harvard.edu

\section{ABSTRACT}

Objective To assess the dietary determinants of serum total cholesterol.

Design Cross-sectional population-based study. Setting Peri-urban region of Dar es Salaam, Tanzania. Participants 347 adults aged 40 years and older from the Dar es Salaam Urban Cohort Hypertension Study.

Main outcome measure Serum total cholesterol measured using a point-of-care device.

Results Mean serum total cholesterol level was $204 \mathrm{mg}$ / $\mathrm{dL}$ (IQR 169-236 mg/dL) in women and $185 \mathrm{mg} / \mathrm{dL}$ (IQR $152-216 \mathrm{mg} / \mathrm{dL}$ ) in men. After adjusting for demographic, socioeconomic, lifestyle and dietary factors, participants who reported using palm oil as the major cooking oil had serum total cholesterol higher by $15 \mathrm{mg} / \mathrm{dL}(95 \%$ $\mathrm{Cl} 1$ to $29 \mathrm{mg} / \mathrm{dL}$ ) compared with those who reported using sunflower oil. Consumption of one or more servings of meat per day ( $p$ for trend $=0.017$ ) and less than five servings of fruits and vegetables per day ( $p$ for trend $=0.024$ ) were also associated with higher serum total cholesterol. A combination of using palm oil for cooking, eating more than one serving of meat per day and fewer than five servings of fruits and vegetables per day, was associated with $46 \mathrm{mg} / \mathrm{dL}$ ( $95 \% \mathrm{Cl} 16$ to $76 \mathrm{mg} / \mathrm{dL}$ ) higher serum total cholesterol.

Conclusions Using palm oil for cooking was associated with higher serum total cholesterol levels in this peri-urban population in Dar es Salaam. Reduction of saturated fat content of edible oil may be considered as a populationbased strategy for primary prevention of cardiovascular diseases.

\section{INTRODUCTION}

Sub-Saharan Africa is facing a burgeoning epidemic of non-communicable diseases (NCDs) due to changing demographic profiles, epidemiological transition, urbanisation and lifestyle changes as a result of economic development as well as increasing survival of patients with HIV. ${ }^{2}$ Nearly half $(46 \%)$ of NCD deaths in sub-Saharan Africa is

\section{Strengths and limitations of this study}

- A reliable point-of care lipid testing system was used to measure serum total cholesterol that has good clinical agreement with laboratory reference methods.

- Potential confounders of the association between diet and serum total cholesterol were systematically measured and adjusted for.

- Only serum total cholesterol was measured instead of a full lipid panel, due to logistic and financial limitations.

The relatively small sample size may have resulted in insufficient statistical power to detect smaller associations.

- The assessment of diet using any method is prone to measurement error, which may have resulted in bias, although differential misreporting of cooking oil by cholesterol level is unlikely.

estimated to be due to cardiovascular diseases (CVD) in $2015^{3}$ and the share of all deaths due to CVD is projected to increase by $17 \%$ by 2030 in this region. ${ }^{3}$

Dyslipidaemia is a well-known risk factor for ischaemic heart disease (IHD), stroke and other vascular diseases. ${ }^{45}$ In middleaged adults, IHD mortality is lower by as much as $30 \%-50 \%$ for every $1 \mathrm{mmol} / \mathrm{L}$ $(38.6 \mathrm{mg} / \mathrm{dL})$ lower serum total cholesterol. ${ }^{5}$ Sub-Saharan Africans have historically had a favourable lipid profile ${ }^{6}$ but hyperlipidaemia is becoming increasingly common in these countries, especially in urban areas. ${ }^{7-9}$ It is estimated that $34 \%$ of IHD deaths in Tanzania are attributable to dyslipidaemia. ${ }^{10}$

A few studies have already explored the relationship between diet and serum total cholesterol in eastern sub-Saharan Africa 
and reported an association between higher intake of meat and lower intake of fish and green vegetables with higher serum total cholesterol. ${ }^{11-15}$ However, two of these studies compared rural and coastal Bantu populations that are known to have, respectively, vegetarian and fishbased diets and did not measure diet in each participant but based their conclusions on known dietary differences between ethnic populations. ${ }^{14} 15$ Another study included participants from rural, urban and pastoral regions of Tanzania but did not report the magnitude of the association ${ }^{12}$ The other two studies conducted in urban Tanzania did not adjust for potential confounders of the relationship between diet and serum total cholesterol. ${ }^{11}{ }^{13}$ There are a few studies from other parts of sub-Saharan Africa that have looked at the association between diet and serum cholesterol. A study conducted in a rural population in Uganda found that eating fewer than five servings of fruits and vegetables daily was associated with higher odds of low high-density lipoprotein (HDL) cholesterol among men, but lower odds among women. ${ }^{16}$ Another study in urban Uganda found lower mean serum total cholesterol in lacto-ovo-vegetarians compared with non-vegetarians. ${ }^{17}$

Another potential dietary determinant of serum cholesterol is the type of oil used in cooking. ${ }^{18}{ }^{19}$ Using cooking oils with higher saturated fat content such as coconut and palm oil has been associated with higher serum total cholesterol levels in clinical trials and observational studies. ${ }^{20}{ }^{21}$ Population-level differences in CVD morbidity and mortality are associated with differences in type of cooking oil in eastern European, ${ }^{22}$ Costa Rica ${ }^{23}$ and Singapore. ${ }^{24}$ Mauritius, Seychelles and Singapore have already implemented policy schemes to reduce saturated fat content of cooking oil as population-level interventions to reduce CVD burden. ${ }^{25-27}$

A thorough understanding of the role of dietary determinants of serum cholesterol will be invaluable in designing population-level interventions to address the growing CVD burden especially considering that treatment for dyslipidaemia is either unavailable or prohibitively expensive for most patients in low-income countries. ${ }^{28}$ Tanzanian diet consists predominantly of carbohydrates (mainly maize, sweet potatoes, cassava and rice) consumed with green leafy vegetables, beans or peas and occasionally with meat or fish. ${ }^{29}$ Palm oil is the major cooking oil, followed by sunflower oil.

We conducted a cross-sectional population-based study to assess the association of type of cooking oil (palm vs sunflower oil) and diet (meat, fish, fruit and vegetable consumption) with serum total cholesterol in an adult population in a peri-urban area of Dar es Salaam. We hypothesised that use of palm oil for cooking and higher intake of meat and lower intake of fruits and vegetables will be associated with higher serum total cholesterol.

\section{METHODS}

\section{Study design and population}

The Dar es Salaam Health and Demographic Surveillance System (HDSS) is a demographic surveillance site in Ukonga and Gongo la Mboto wards of Dar es Salaam, Tanzania, with over 100000 enumerated individuals living in 21000 households followed since December 2011. For the Dar es Salaam Urban Cohort Hypertension Study, we randomly selected one large and one small neighbourhood in the HDSS and contacted all adult residents aged 40 years and older, who had been registered in the HDSS database in 2011 or 2012. A random subsample of one-fifth of the eligible participants was selected for additional assessment of diet and measurement of serum total cholesterol. The size of this subsample was determined largely based on the availability of resources. Pregnant women and those who were physically and mentally incapable of completing the interview and measurements were excluded. The participant selection flowchart is shown in figure 1. Face-to-face interviews and measurements were conducted in participants' homes from March to June 2014 by six trained interviewers. All interviewers had previous experience conducting public health surveys. For this study, interviewers received 5 days of training and 2 days of field practice in a nearby neighbourhood. At least three attempts were made to contact all potential participants. Written informed consent was obtained from all participants.

\section{Measurements}

Non-fasting serum total cholesterol was measured from $30 \mu \mathrm{L}$ of finger-prick capillary blood samples using Cardiochek PA devices (Polymer Technology Systems, Indianapolis, USA) ${ }^{3031}$ The overall coefficient of variation for this device for total cholesterol has been determined to be in the range of $1.3 \%-2.9 \% .^{30}$

Data on diet were collected using a semiquantitative food frequency questionnaire (FFQ). The FFQ assessed intake of 179 food and drink items over the past 30 days. A shorter 85-item version of this instrument has been previously used in Tanzania. ${ }^{32}$ Nutrient intakes were calculated by multiplying the frequency of food consumption measured from FFQ by the nutrient content of the specified portion size using the Tanzanian food composition table. ${ }^{33}$ Meat intake was defined to include all red and white meat consumption, excluding fish consumption. Fruit and vegetable intake was defined to include consumption of all fruits and vegetables, except for root vegetables and fruit juice. An additional question was asked to assess the main type of cooking oil: 'What is the kind of oil used most often in your home for frying food?'. Frying is the most common cooking technique involving oil use in this region. The reference to a cooking technique was made to distinguish it from other oils that may be used in a household, such as fuels.

All participants completed a socioeconomic, demographic and lifestyle questionnaire and had their height, weight, waist circumference, hip circumference and blood pressure measured by trained interviewers. Some 


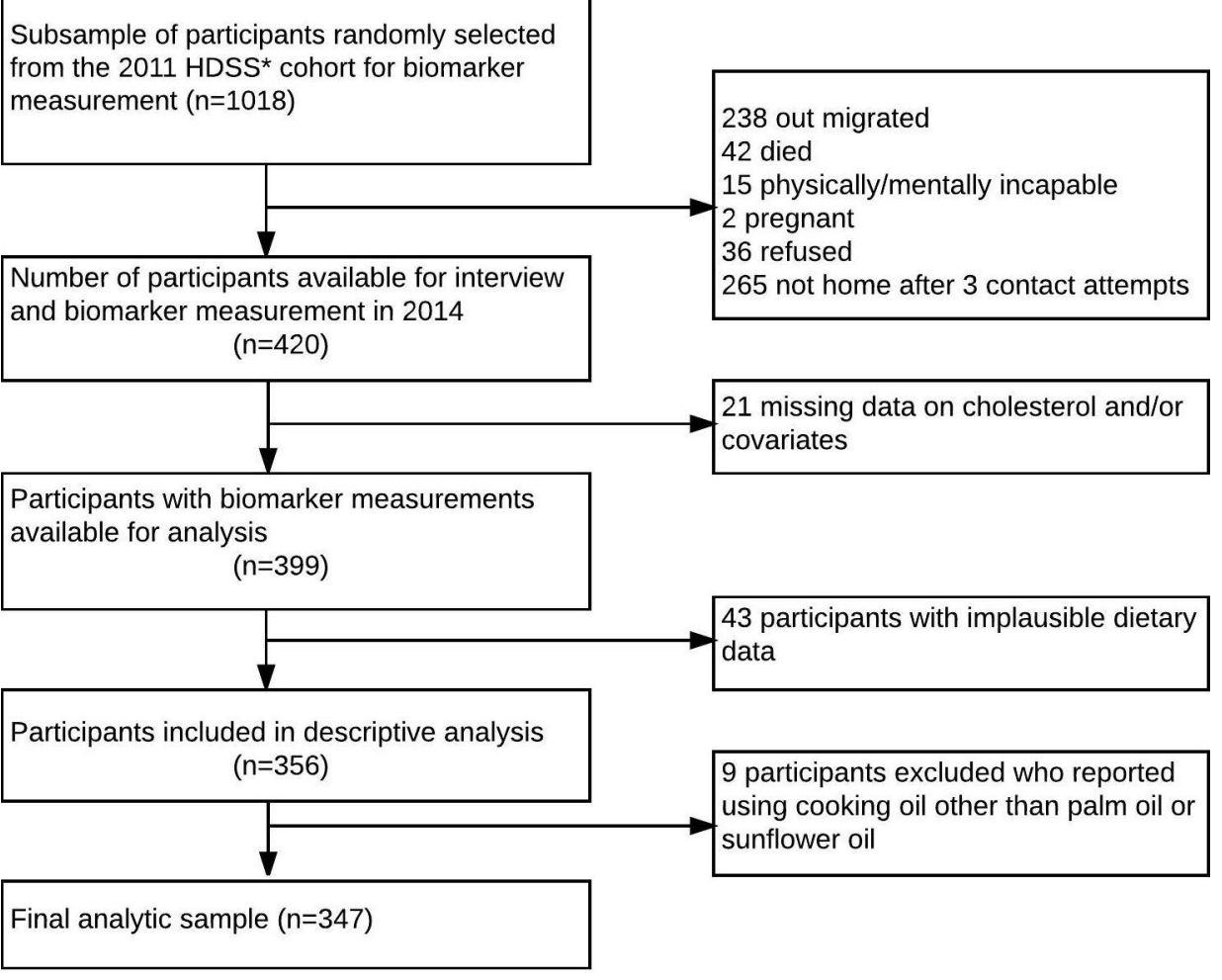

*Dar Es Salaam Health and Demographic Surveillance System

Figure 1 Selection of study participants, Dar es Salaam Urban Cohort Hypertension biomarker substudy, 2014.

demographic information (age, sex, neighbourhood, components of wealth index) was taken from the HDSS baseline interview. Body mass index was calculated as weight $(\mathrm{kg})$ divided by height $(\mathrm{m})$ squared, and categorised as underweight $(<18.5)$, normal $(18.5$ to $<25.0)$, overweight (25.0 to $<30.0)$ and obese $(\geq 30.0) .{ }^{34}$ Physical activity was assessed using the Global Physical Activity Questionnaire in the domains of work, transportation and leisure, ${ }^{35}$ and categorised into tertiles of metabolic equivalent hours per week. To measure socioeconomic status, we created a household wealth index using a principal component analysis of household characteristics (floor material, roof material, wall material, electricity), household assets (television, radio, shop, sewing machine, sofa, fan, iron, stove with oven, stove without oven, dining table, cupboard, watch, mobile phone, bike, motorcycle, cart, car, motorboat) and animal ownership (goats, sheep, chicken/ducks, pigs). ${ }^{36}$ The household wealth index was categorised into tertiles.

\section{Statistical analysis}

We excluded participants with implausible dietary data (total energy intake $<500$ or $>5000 \mathrm{kcal} /$ day), and with missing data on serum total cholesterol, diet and/or any of the potential covariates.

$\chi^{2}$ tests were used to assess binary variables, F-tests were used for categorical variables and tests of linear trend based on median value within each category for ordinal variables with a linear association with serum total cholesterol (ie, age, wealth index and food consumption categories). Mean differences and $95 \%$ CIs in serum total cholesterol across categories of dietary factors including cooking oil were estimated using multivariable linear regression. Potential confounders were included in the model based on a priori knowledge of lifestyle and sociodemographic determinants of diet and serum total cholesterol. The fully adjusted model included age, sex, total energy intake, physical activity, alcohol consumption, wealth index and employment status as covariates. We also adjusted for interviewer to remove the effect of any extraneous variation in measurement of subjective risk factors across interviewers. ${ }^{37}{ }^{38}$ We examined interactions of potential determinants of serum total cholesterol with sex, but no interactions were statistically significant at 0.2 level; therefore, we did not include these product terms in the final model. We conducted sensitivity analyses by excluding 16 participants who reported either being previously diagnosed with hypercholesterolaemia or currently taking cholesterol-lowering medications or being advised by a health professional to modify diet to lower cholesterol.

All analyses were performed using STATA version 13.1 (STATA corporation, Texas, USA). We followed the standards of the Strenghtening the Reporting System of Observational Studies in Epidemiology (STROBE) in this manuscript (see Research Checklist in Supplementary Data) .

\section{RESULTS}

A total of 420 participants were enrolled for the random subsample with diet and cholesterol measurements. Among these, data on serum total cholesterol and 
selected covariates were available for 399 participants. We excluded 43 participants due to implausible caloric intake. In addition, after descriptive analyses we excluded nine $(2 \%)$ participants who reported using cooking oils other than palm or sunflower oil. The final analytic sample included 347 participants (figure 1).

Forty-two per cent of the participants $(n=347)$ were men (table 1 ). Mean age of men was 55 years (SD 11), and that of women was 52 (SD 10). Forty-four per cent of the women $(n=202)$ and $19 \%$ of men $(n=145)$ were obese, and one-third of men and women were overweight. Mean energy intake per day was $2413 \mathrm{kcal}$. Thirty-seven per cent of men and $54 \%$ of women were hypercholesterolemic (ie, had total cholesterol $\geq 200 \mathrm{mg} / \mathrm{dL}$ ). Mean serum total cholesterol in women was $204 \mathrm{mg} / \mathrm{dL}$ (95\% CI 197 to $211 \mathrm{mg} / \mathrm{dL}$ ) and was significantly higher than that of men at $185 \mathrm{mg} / \mathrm{dL}$ (177 to $193 \mathrm{mg} / \mathrm{dL})$. Serum total cholesterol levels were higher in older age groups.

Seventy-nine per cent of participants reported using palm oil as the major cooking oil and the rest reported using sunflower oil (table 1). Those who reported using palm oil were most likely to be in the poorest tertile of wealth, whereas those who reported using sunflower oil were most likely to be in the wealthiest tertile $(p<0.001)$. Those who reported using sunflower oil had a higher energy intake $(\mathrm{p}=0.04)$, and reported consuming meat $(\mathrm{p}=0.004)$ and dairy $(\mathrm{p}=0.02)$ more frequently than those who reported using palm oil. Mean serum total cholesterol in those who reported using palm oil was $199 \mathrm{mg}$ / dL (193-205) and was significantly higher than those who reported using sunflower oil $184 \mathrm{mg} / \mathrm{dL}$ (173-195).

In the minimally adjusted model (with interviewer as the only covariate), those who reported using palm oil as the major cooking oil had serum total cholesterol levels higher by $11 \mathrm{mg} / \mathrm{dL}$ ( -2 to $24 \mathrm{mg} / \mathrm{dL}$ ) compared with those who reported using sunflower oil (table 2). After adjusting for covariates, participants who used palm oil for cooking had $15 \mathrm{mg} / \mathrm{dL}(1-29 \mathrm{mg} / \mathrm{dL})$ higher serum total cholesterol (figure 2). The negative confounding was mostly due to the negative correlation between palm oil use and female gender and meat intake (both variables were positively correlated with serum total cholesterol). Serum total cholesterol was also higher in participants who ate meat more frequently ( $\mathrm{p}$ for trend 0.017 ) after adjusting for potential confounders. Specifically, those who ate more than one serving of meat per day had $18 \mathrm{mg} / \mathrm{dL}$ (-3 to $39 \mathrm{mg} / \mathrm{dL})$ higher serum total cholesterol compared with those who ate less than one serving per week. In this relationship, higher total energy intake was the major confounder with a positive correlation with meat intake but negative correlation with serum total cholesterol. Consumption of more than seven servings of fruits and vegetables per day was associated with $13 \mathrm{mg}$ / dL $(-3$ to $29 \mathrm{mg} / \mathrm{dL})$ lower serum total cholesterol, compared with consumption of fewer than five servings per day ( $\mathrm{p}$ for trend 0.024). A combination of using palm oil for cooking, eating more than one serving of meat per day and fewer than five servings of fruits and vegetables per day, was associated with $46 \mathrm{mg} / \mathrm{dL}$ (16 to $76 \mathrm{mg} / \mathrm{dL}$ ) higher serum total cholesterol.

We found similar associations after excluding 16 participants who reported either being previously diagnosed with hypercholesterolaemia or currently taking cholesterol-lowering medications or being advised by a health professional to modify diet to lower cholesterol. Those who used palm oil had $17 \mathrm{mg} / \mathrm{dL}$ (2-32 mg/dL) higher serum total cholesterol compared with those who used sunflower oil (table 2). There was no significant association between percentage of energy from saturated fat and total serum cholesterol after adjusting for total fat, total protein and total carbohydrate (adjusted mean difference $1 \mathrm{mg} / \mathrm{dL}$ ( -3 to $5 \mathrm{mg} / \mathrm{dL}$ ))

Only $11 \%$ of women and $5 \%$ of men reported having ever had their cholesterol levels checked (table 1; figure 3). Among those with hypercholesterolaemia $(n=164), 2 \%$ of men ( 1 of 54$)$ and $11 \%$ of women (12 of 110) reported being notified by doctors about it, and $2 \%$ of men and $7 \%$ of women reported taking cholesterol-lowering medications.

\section{DISCUSSION}

In this cross-sectional study among middle-aged and older adults in a peri-urban ward in Dar es Salaam, Tanzania, we found a high prevalence of hypercholesterolaemia. Slightly more than a third of men and half of women had serum total cholesterol levels greater than or equal to $200 \mathrm{mg} / \mathrm{dL}$. After adjusting for major confounders, serum total cholesterol was higher by $15 \mathrm{mg} / \mathrm{dL}$ among those who used palm oil compared with those who used sunflower oil as the major cooking oil, and showed a significant increasing trend with higher consumption of meat $(\mathrm{p}=0.017)$ and lower consumption of fruits and vegetables $(\mathrm{p}=0.01)$.

Mean serum total cholesterol levels for men and women were similar to that reported in other studies conducted in other urban Tanzanian populations. ${ }^{32} 3940$ A repeated cross-sectional study reported an increase over time in the prevalence of hypercholesterolaemia in Dar es Salaam with a prevalence of $17 \%$ in 1987 vs $30 \%$ in 1998 in men, and $7 \%$ vs $50 \%$ in women. ${ }^{39}$ The prevalence of hypercholesterolaemia in our sample was higher than that reported by studies conducted between 2008 and 2014 in rural Uganda ( $3 \%$ men, $8 \%$ women), ${ }^{9}$ peri-urban Nigeria $(2 \% \text { men, } 6 \% \text { women })^{8}$ and blacks in urban South Africa (25\% men, 23\% women), ${ }^{41}$ but is lower than that reported in a study from Senegal ( $54 \%$ men, $61 \%$ women) that included both urban and rural participants. ${ }^{42}$

Our estimated association between palm oil versus sunflower oil use and serum total cholesterol is consistent with findings from dietary observational studies and intervention trials. A recent meta-analysis of 30 dietary intervention trials comparing diets rich in palm oil with diets rich in vegetable oils low in saturated fatty acids showed significantly higher total $(13.5 \mathrm{mg} / \mathrm{dL})$ and low-density lipoprotein (LDL) $(9.3 \mathrm{mg} / \mathrm{dL})$ cholesterol, and slightly higher HDL cholesterol $(0.8 \mathrm{mg} / \mathrm{dL}) 2-16$ 
Table 1 Participants' characteristics in Dar es Salaam Urban Cohort Hypertension biomarker substudy, 2014

\begin{tabular}{|c|c|c|c|c|c|}
\hline Variable & All $(n=347)$ & Men $(n=145)$ & Women $(n=202)$ & $\begin{array}{l}\text { Use palm } \\
\text { oil }(n=274)\end{array}$ & $\begin{array}{l}\text { Use } \\
\text { sunflower } \\
\text { oil }(n=73)\end{array}$ \\
\hline \multicolumn{6}{|l|}{ Age } \\
\hline $40-49$ & $150(43)$ & $56(39)$ & $94(47)$ & $123(45)$ & 27 (37) \\
\hline $50-59$ & $113(33)$ & $43(30)$ & $70(35)$ & $82(30)$ & $31(42)$ \\
\hline 60 and above & $84(24)$ & $46(32)$ & 38 (19) & $69(25)$ & $15(21)$ \\
\hline \multicolumn{6}{|l|}{ Employment status } \\
\hline Unemployed & $83(24)$ & $14(10)$ & $69(34)$ & $70(26)$ & $13(18)$ \\
\hline $\begin{array}{l}\text { Employed (includes self- } \\
\text { employed) }\end{array}$ & $238(69)$ & $112(77)$ & $126(62)$ & $183(67)$ & $55(75)$ \\
\hline Retired & $26(7)$ & $19(13)$ & 7 (3) & $21(8)$ & $5(7)$ \\
\hline \multicolumn{6}{|l|}{$\begin{array}{l}\text { Household wealth } \\
\text { index }\end{array}$} \\
\hline Tertile 1, poorest & $115(33)$ & $49(34)$ & $66(33)$ & $109(40)$ & $6(8)$ \\
\hline Tertile 2 & $117(34)$ & $53(37)$ & $64(32)$ & $90(33)$ & $27(37)$ \\
\hline Tertile 3, wealthiest & $115(33)$ & $43(30)$ & $72(36)$ & $75(27)$ & $40(55)$ \\
\hline \multicolumn{6}{|l|}{ BMI $\left(\mathrm{kg} / \mathrm{m}^{2}\right)$} \\
\hline Underweight $(<18.50)$ & $19(5)$ & $13(9)$ & $6(3)$ & $19(7)$ & $0(0)$ \\
\hline $\begin{array}{l}\text { Normal weight } \\
(18.50 \text { to }<25.00)\end{array}$ & $100(29)$ & $56(39)$ & $44(22)$ & $91(33)$ & $9(12)$ \\
\hline $\begin{array}{l}\text { Overweight } \\
(25 \text { to }<30.00)\end{array}$ & $112(32)$ & $48(33)$ & $64(32)$ & $81(30)$ & $31(42)$ \\
\hline Obese $(\geq 30.00)$ & $116(33)$ & 28 (19) & $88(44)$ & $83(30)$ & $33(45)$ \\
\hline \multicolumn{6}{|l|}{ Physical activity } \\
\hline $\begin{array}{l}\text { Tertile 1(0-14 MET hours/ } \\
\text { week) }\end{array}$ & $123(35)$ & $46(32)$ & $77(38)$ & $96(35)$ & $27(37)$ \\
\hline $\begin{array}{l}\text { Tertile 2(15-112 } \\
\text { MET hours/week) }\end{array}$ & $108(31)$ & $38(27)$ & 70 (35) & $86(31)$ & $22(30)$ \\
\hline $\begin{array}{l}\text { Tertile 3(113-840 } \\
\text { MET hours/week) }\end{array}$ & $116(33)$ & $61(42)$ & $55(27)$ & $92(34)$ & $24(33)$ \\
\hline \multicolumn{6}{|l|}{ Alcohol drinking ${ }^{*}$} \\
\hline Non-drinker & $286(82)$ & $103(71)$ & $183(91)$ & $225(82)$ & $61(84)$ \\
\hline \multicolumn{6}{|l|}{ Smoking } \\
\hline Non-smoker & $278(81)$ & $85(59)$ & $193(97)$ & $210(78)$ & $68(93)$ \\
\hline Former smoker & 43 (13) & $39(27)$ & $4(2)$ & 38 (14) & $5(7)$ \\
\hline Current smoker & $22(6)$ & $19(13)$ & $3(2)$ & $22(8)$ & $0(0)$ \\
\hline \multicolumn{6}{|l|}{ Dietary variables } \\
\hline $\begin{array}{l}\text { Palm oil as major } \\
\text { cooking oil }\end{array}$ & $274(79)$ & $119(82)$ & $155(77)$ & & \\
\hline \multicolumn{6}{|l|}{ Meat intake } \\
\hline$<1$ serving/week & $41(12)$ & $21(14)$ & $20(10)$ & $36(13)$ & $5(7)$ \\
\hline 1-6 servings/week & $173(50)$ & $55(38)$ & $118(58)$ & $145(53)$ & $28(38)$ \\
\hline$\geq 1$ servings/day & $133(38)$ & $69(48)$ & $64(32)$ & $93(34)$ & $40(55)$ \\
\hline \multicolumn{6}{|l|}{ Fish intake } \\
\hline$<1$ serving/week & $41(12)$ & $13(9)$ & $28(14)$ & $31(11)$ & $10(14)$ \\
\hline 1-7 servings/week & $196(56)$ & $76(52)$ & $120(59)$ & $154(56)$ & $42(58)$ \\
\hline$>1$ servings/day & $110(32)$ & $56(39)$ & $54(27)$ & $89(32)$ & $21(29)$ \\
\hline
\end{tabular}


Table 1 Continued

\begin{tabular}{|c|c|c|c|c|c|}
\hline Variable & All $(n=347)$ & Men $(n=145)$ & Women $(n=202)$ & $\begin{array}{l}\text { Use palm } \\
\text { oil }(n=274)\end{array}$ & $\begin{array}{l}\text { Use } \\
\text { sunflower } \\
\text { oil ( } n=73)\end{array}$ \\
\hline \multicolumn{6}{|l|}{ Dairy intake } \\
\hline$<1$ serving/week & $159(46)$ & $63(43)$ & $96(48)$ & $136(50)$ & $23(32)$ \\
\hline 1-6 servings/week & $133(38)$ & $65(45)$ & $68(34)$ & $99(36)$ & $34(47)$ \\
\hline$\geq 1$ servings/day & $55(16)$ & $17(12)$ & $38(19)$ & $39(14)$ & $16(22)$ \\
\hline \multicolumn{6}{|l|}{ Fruit and vegetable } \\
\hline$<5$ servings/day & $121(35)$ & $49(34)$ & $72(36)$ & $101(37)$ & $20(27)$ \\
\hline $5-7$ servings/day & $68(20)$ & $26(20)$ & $42(21)$ & $54(20)$ & $14(19)$ \\
\hline$>7$ servings/day & $158(46)$ & $70(48)$ & $88(44)$ & $119(43)$ & $39(53)$ \\
\hline \multicolumn{6}{|l|}{ Nuts and legumes } \\
\hline$<1$ serving/week & $27(8)$ & $7(5)$ & $20(10)$ & $17(6)$ & $10(14)$ \\
\hline 1-7 servings/week & $200(58)$ & $87(60)$ & $113(56)$ & $162(59)$ & $38(52)$ \\
\hline$>1$ servings/day & $120(35)$ & $51(35)$ & $69(34)$ & $95(35)$ & $25(34)$ \\
\hline $\begin{array}{l}\text { Total energy intake (kcal/ } \\
\text { day) } \dagger\end{array}$ & $2413(1701,3215)$ & $2629(1780,3216)$ & $2313(1617,3207)$ & $2369(1654,3150)$ & $\begin{array}{l}2743(1865 \\
3606)\end{array}$ \\
\hline \multicolumn{6}{|l|}{ Fat intake $\dagger$} \\
\hline Total fat (\% of energy) & $17(15,20)$ & $17(15,21)$ & $17(15,20)$ & $17(14,20)$ & $20(15,22)$ \\
\hline Saturated fat (\% energy) & $10(8,13)$ & $10(8,13)$ & $10(8,12)$ & $10(8,13)$ & $10(8,11)$ \\
\hline $\begin{array}{l}\text { Monounsaturated fat (\% } \\
\text { of energy) }\end{array}$ & $4(3,5)$ & $4(3,5)$ & $4(3,5)$ & $4(3,5)$ & $4(4,5)$ \\
\hline $\begin{array}{l}\text { Polyunsaturated fat (\% of } \\
\text { energy) }\end{array}$ & $2(1,2)$ & $2(1,2)$ & $2(1,2)$ & $1(1,2)$ & $2(1,2)$ \\
\hline \multicolumn{6}{|l|}{ Cholesterol } \\
\hline $\begin{array}{l}\text { Serum total cholesterol } \\
(\mathrm{mg} / \mathrm{dL}) \ddagger\end{array}$ & $196(3)$ & $185(4)$ & $204(4)$ & $199(3)$ & $184(6)$ \\
\hline Hypercholesterolaemia $\S$ & $164(47)$ & $54(37)$ & $110(54)$ & $135(49)$ & $29(40)$ \\
\hline $\begin{array}{l}\text { Cholesterol level was } \\
\text { previously checked }\end{array}$ & $29(18)$ & $7(13)$ & $22(20)$ & $13(10)$ & $16(55)$ \\
\hline $\begin{array}{l}\text { Previously diagnosed } \\
\text { hypercholesterolaemia }\end{array}$ & $13(8)$ & $1(2)$ & $12(11)$ & $5(4)$ & $8(28)$ \\
\hline $\begin{array}{l}\text { Currently taking } \\
\text { cholesterol lowering } \\
\text { medications }\end{array}$ & $9(5)$ & $1(2)$ & $8(7)$ & $3(2)$ & $6(21)$ \\
\hline
\end{tabular}

Number (\%) reported for all variables, except as specified $b$ and $c$ below.

${ }^{*}$ According to report of drinking alcohol in the past 30 days.

†Total energy and fat intake, which is reported as median (IQR).

$\ddagger$ Serum total cholesterol, reported as mean (SE).

$\S$ Hypercholesterolaemia defined as total cholesterol $\geq 200 \mathrm{mg} / \mathrm{dL}$.

BMI, body mass index; MET,metabolic equivalent.

weeks after intervention. ${ }^{21}$ In addition, a large casecontrol study conducted in Costa Rica found that palm oil use compared with soybean oil use was independently associated with $33 \%$ higher odds of myocardial infarction. ${ }^{23}$

Higher meat consumption has previously been reported to be associated with higher serum total cholesterol in Tanzania. ${ }^{12}{ }^{13}$ Similar to our finding, daily consumption of meat was found to be associated with $24 \mathrm{mg} /$ dL higher serum total cholesterol levels, after adjusting for age, select dietary components and resting energy expenditure. ${ }^{13}$ Observational studies have also reported lower LDL cholesterol by $2.3 \mathrm{mg} / \mathrm{dL}$ for every additional serving of fruits or vegetables. ${ }^{43-45}$ The magnitude of $13 \mathrm{mg} / \mathrm{dL}$ reduction in serum total cholesterol that we found for six or more servings of fruits and vegetables per day is consistent with the reductions in LDL cholesterol seen in these studies. We did not find significant associations between serum total cholesterol and fish intake in men, as reported in previous studies. ${ }^{12} 13$ This could have 


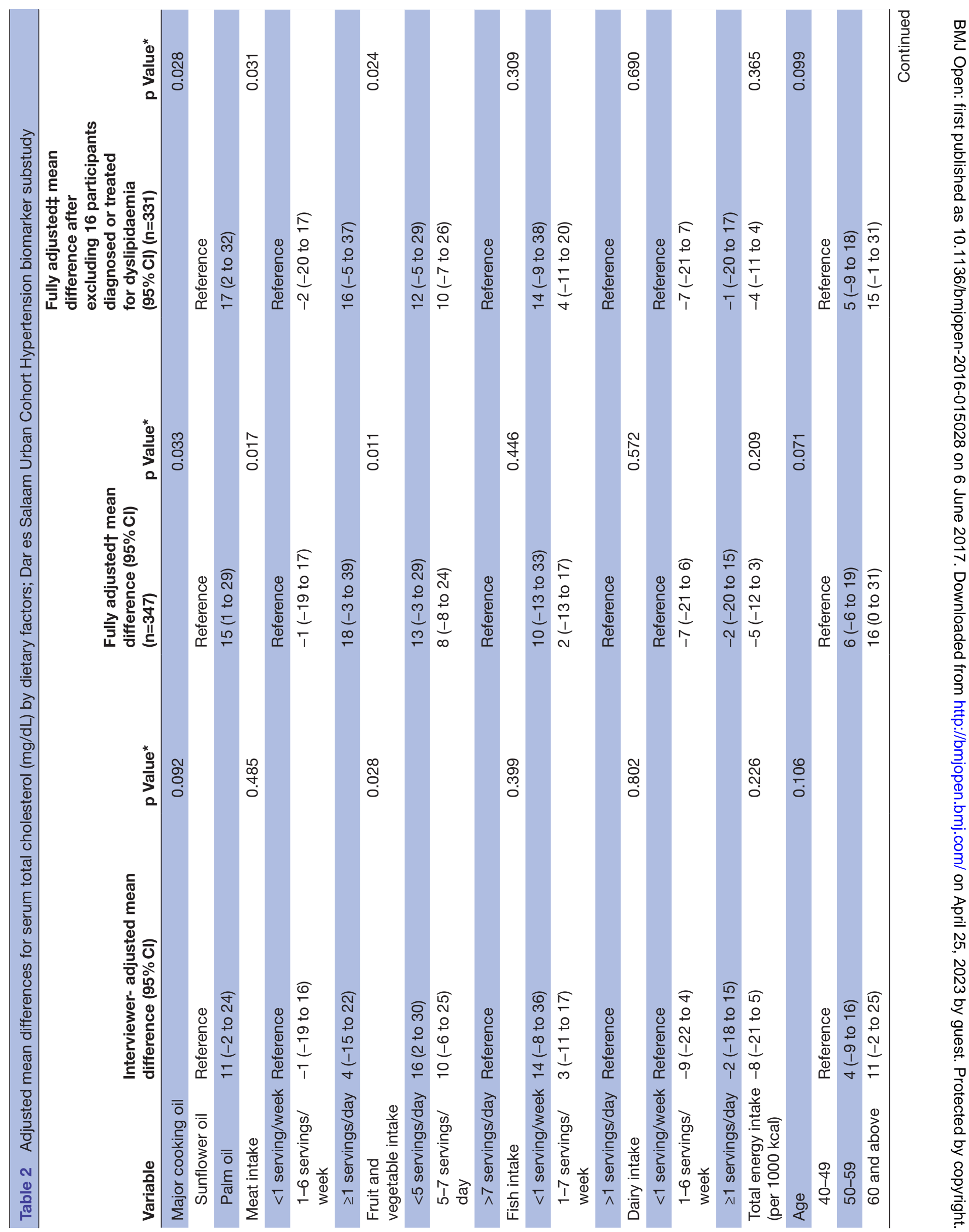




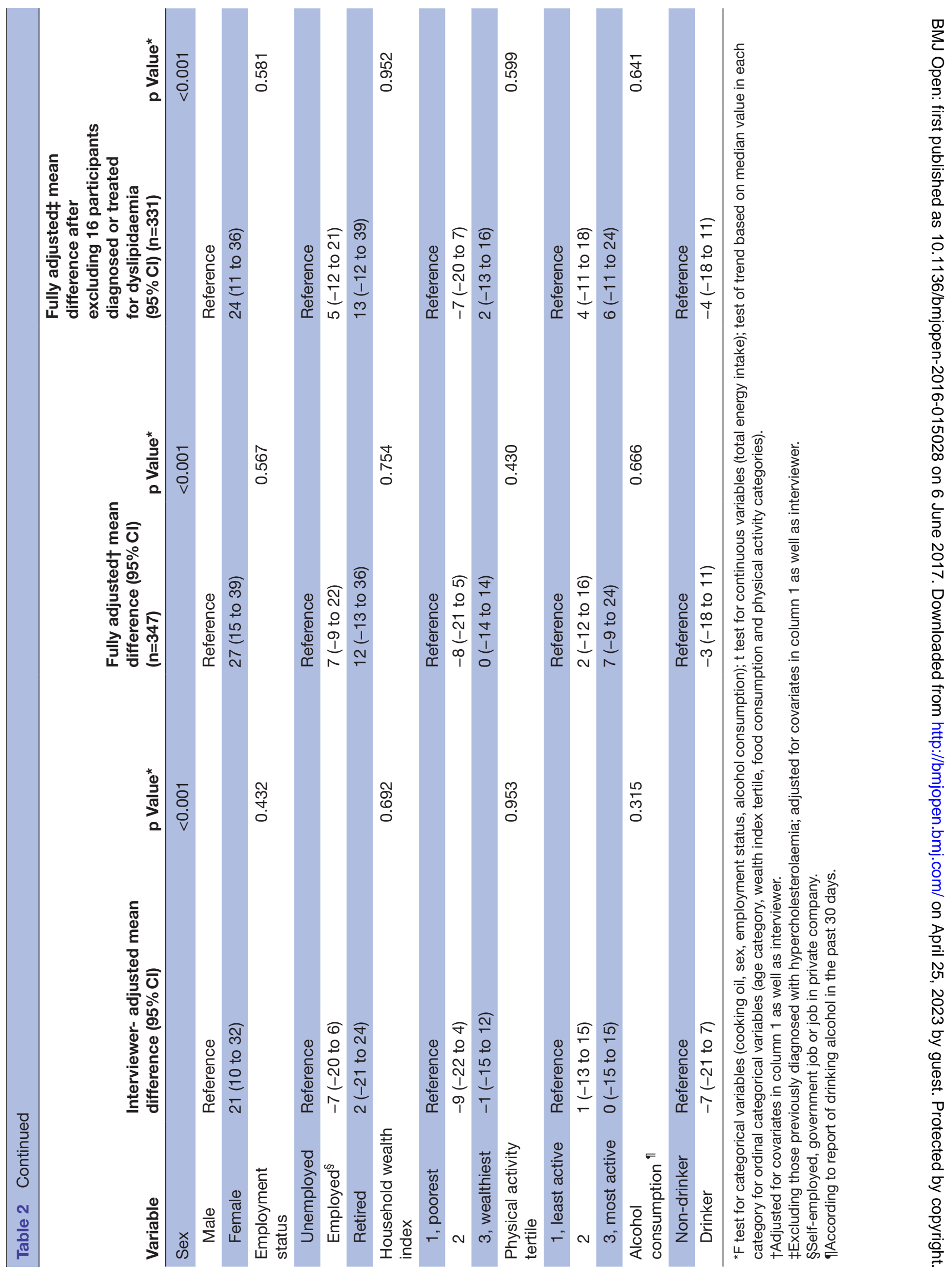




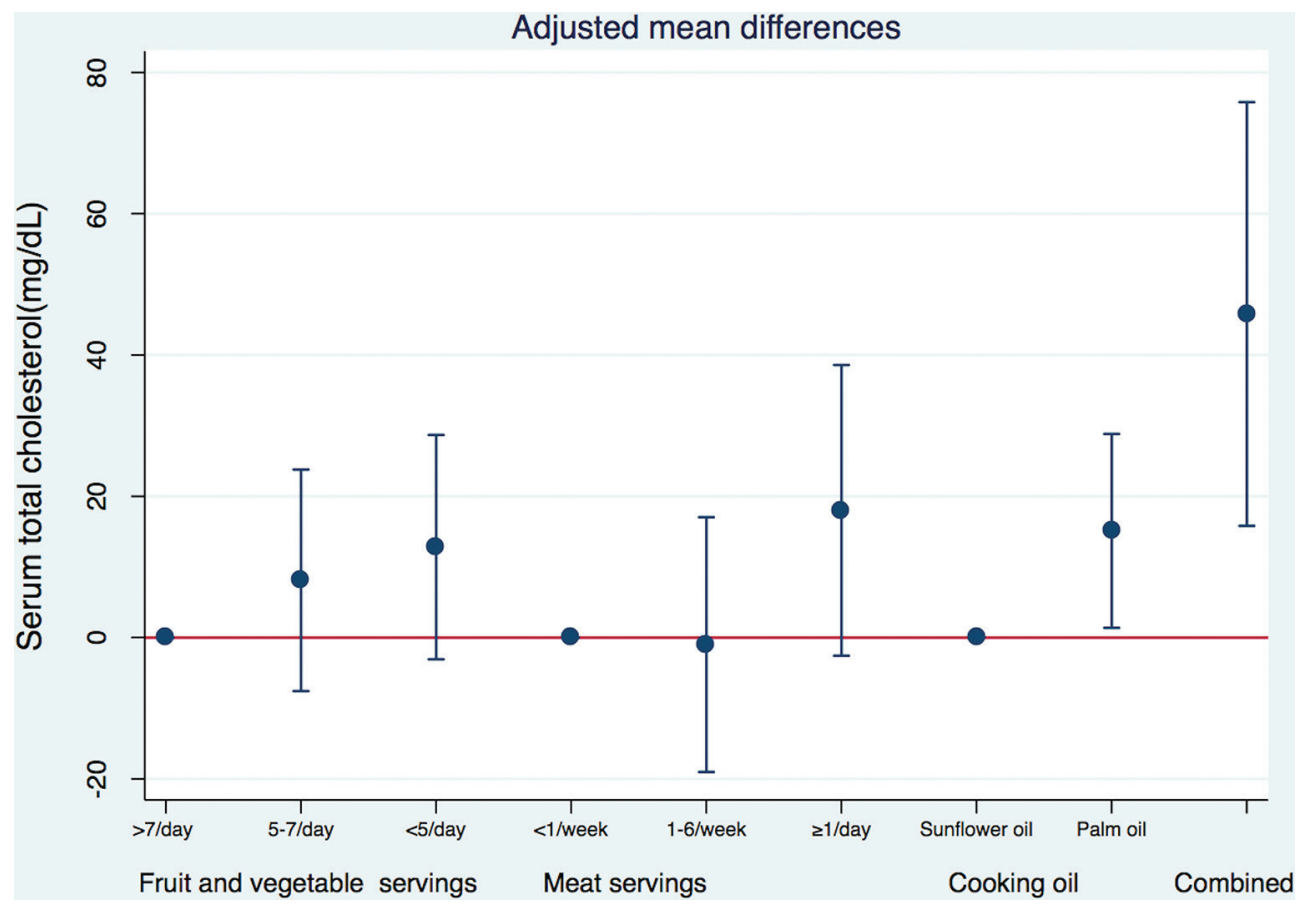

Figure 2 Association between diet and serum total cholesterol. Values were adjusted for age, sex, socioeconomic status, food consumption frequency, total energy intake, major cooking oil used, physical activity and alcohol consumption.

been due to insufficient statistical power due to smaller expected effect size for fish intake or higher measurement error.

Palm oil is obtained mostly from the middle section (pulp) of the fruits of the tropical plant Elaeis guineensis. ${ }^{46}$ Compared with most other vegetable oils, it contains less unsaturated fat and more saturated fat (nearly 40\%-50\% of total fat content) with the majority being palmitic acid. ${ }^{46}$ However, compared with saturated fat from animal sources, palm oil may have a smaller impact on serum cholesterol because almost $70 \%$ of the palmitic acid is located in the first and third position of the triglycerides, which is less absorbable than those in the second position (which is the most common position of palmitic acid
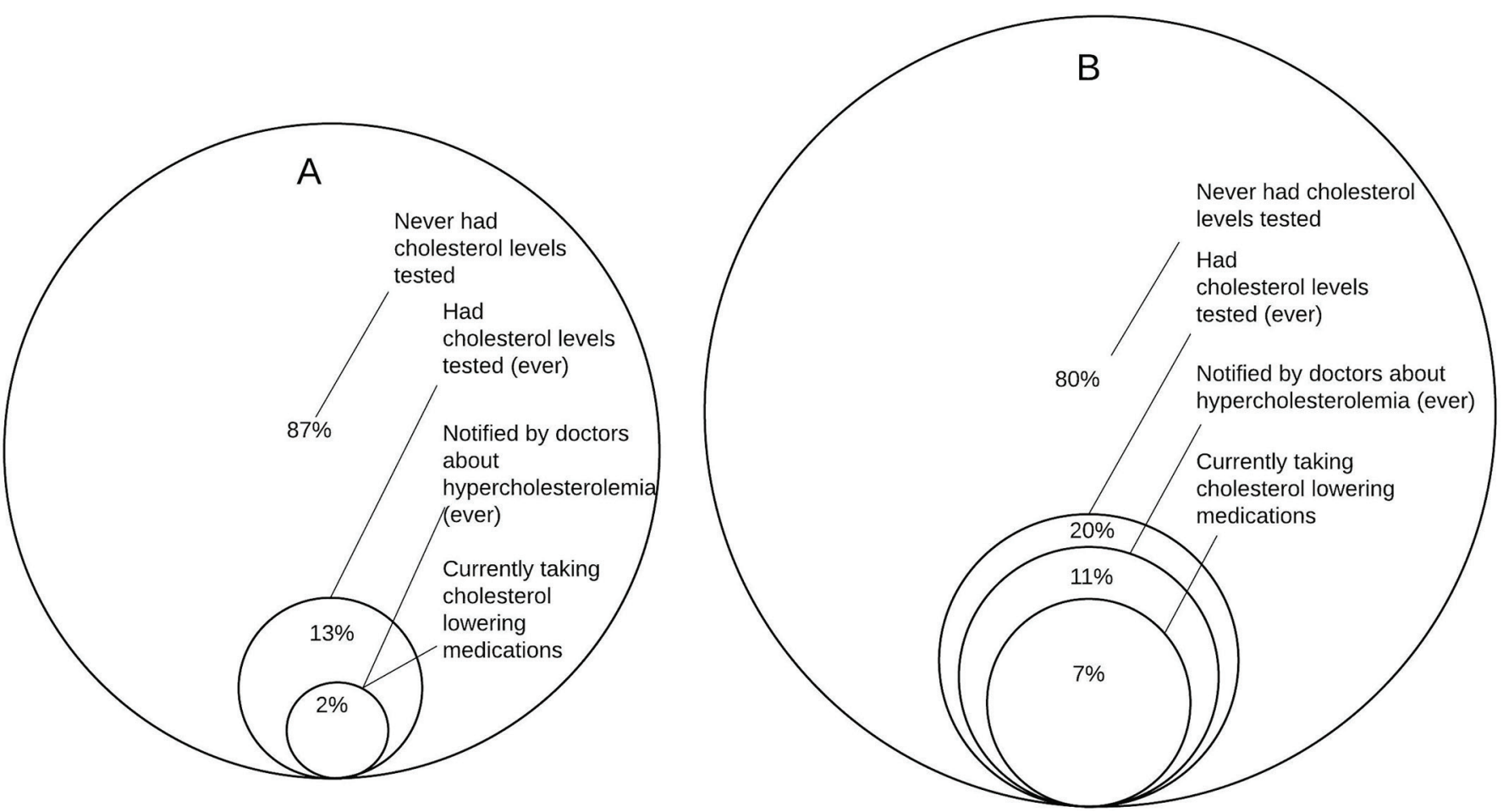

Figure 3 Diagnosis, awareness and treatment of hypercholesterolaemia in men ( $\mathrm{A} ; \mathrm{n}=54$ for all percentages) and women ( $\mathrm{B}$; $\mathrm{n}=110$ for all percentages) in the Dar es Salaam Urban Cohort Hypertension biomarker substudy, 2014. 
in animal fats). ${ }^{478}$ Despite these biological differences, evidence from both observational and experimental studies, as summarised above, points to harmful effects of palm oil on serum cholesterol and CVD when substituted for unsaturated fatty acids.

Our study has several limitations. First, due to logistic and financial limitations, we measured serum total cholesterol instead of a full lipid panel. However, data from recent meta-analysis of randomised trials suggest that the effect of substituting palm oil for vegetable oils low in saturated fat on LDL cholesterol levels is larger than that on HDL. ${ }^{21}$ Second, the assessment of diet using any method is prone to measurement error which may have resulted in bias. However, it is unlikely that participants with higher serum cholesterol differentially misreport using palm oil in cooking, limiting the impact of such measurement error on our results. Third, the relatively small sample size may have resulted in insufficient statistical power to detect some associations (eg, with fish intake). There are some important strengths of this study. To our knowledge, this is the first population-based study to report an association between using palm oil for cooking and serum total cholesterol in East Africa. We used a reliable point-of-care lipid testing system that has good clinical agreement with laboratory reference methods. ${ }^{31}$ We systematically collected data on and adjusted for potential confounders of the association between diet and serum total cholesterol.

Were our findings to be replicated in other studies, they could have important implications for nutritional policies aimed at CVD prevention. Palm oil is now the major edible oil in Tanzania and many other low/ middle income countries. ${ }^{49}$ In Tanzania, more than half of the palm oil is imported,$^{50}$ and it is the second most imported agricultural commodity. ${ }^{51}$ In our study population, more than three-quarters of participants used palm oil (cost 2500 Tanzanian Shillings $\approx$ USD 1.1 per litre) as the major cooking oil with $94 \%$ of participants $(n=119)$ in the lowest tertile of wealth using palm oil. Even in the wealthiest tertile, only $34 \%(n=123)$ used sunflower oil (cost 4000 Tanzanian Shillings $\approx$ USD 1.8 per litre). These socioeconomic differentials in palm oil use may affect socioeconomic disparities in CVD in the coming years with the burden shifting more swiftly to poorer households.

Policy interventions to address composition of dietary fat have previously been implemented in Seychelles, Mauritius and Singapore. ${ }^{27} 5253$ In the early 1990s, Seychelles implemented a nationwide programme that included increasing use of unsaturated vegetable oils, which may have contributed to the fairly high rate of decline in age-standardised CVD mortality of $44 \%$ in men and $28 \%$ in women over a 22-year period. ${ }^{25} 5254$ A national NCD prevention programme was also implemented in Mauritius in the late 1980s to reduce saturated fat content of cooking oil by changing the government-subsidised ration oil from palm oil to soybean oil. The observed $31 \mathrm{mg} / \mathrm{dL}$ reduction in serum total cholesterol over a period of 5 years ${ }^{26} 53$ is compatible with the estimated impact of replacing palm oil with unsaturated vegetable oil estimated in a recent meta-analysis of dietary intervention trials. ${ }^{55}$ Similar policies can be considered to reduce palm oil intake in Tanzania. However, it should be noted that edible oils are viewed as necessities, ${ }^{56}$ and increasing their price (eg, by taxation) without providing healthier alternatives at comparable prices may have unintended adverse consequences on overall energy consumption or food security. ${ }^{57-59}$ Reducing saturated fat in edible oil by mixing it with other unsaturated oils has been proposed as a potential intervention in Costa Rica and India, ${ }^{23}{ }^{60}$ and could be a feasible short-term intervention in Tanzania.

In conclusion, our results indicate that using palm oil for cooking, lower intake of fruits and vegetables and higher intake of meat is strongly associated with higher serum total cholesterol in this peri-urban population in Tanzania. Our findings are generalisable to other peri-urban populations in Tanzania and possibly to populations in low-income countries with a similar dietary profile. Dietary policies aimed at altering the targets identified in this study can be used to improve lipid profiles and therefore prevent CVDs in these countries.

\section{Author affiliations}

${ }^{1}$ Department of Global Health and Population, Harvard T.H. Chan School of Public Health, Boston, Massachusetts, USA

${ }^{2}$ Department of Epidemiology, Harvard T.H. Chan School of Public Health, Boston, Massachusetts, USA

${ }^{3}$ Department of Epidemiology and Biostatistics, School of Public Health, Muhimbili University of Health and Allied Sciences, Dar es Salaam, United Republic of Tanzania ${ }^{4}$ Department of Nutrition, Harvard T.H. Chan School of Public Health, Boston,

Massachusetts, USA

${ }^{5}$ World food program, Dar es Salaam and Tumaini Hospital, Dar es Salaam, Tanzania

Acknowledgements The authors thank participants, interviewers, data entry clerks, administrative and support staff, who generously contributed time and effort for this study, and Patrick Kazonda for meticulous data management.

Contributors GD, JK, GHL and RMZ conceived and designed the study. GD obtained the funding. SSK and SF analysed the data. GD and SSK interpreted the data and drafted the article, which was revised critically for substantive content by all authors, who approved the final version for publication. GD, SSK, SF and RMZ had full access to all of the data (including statistical reports and tables) in the study and can take responsibility for the integrity of the data and the accuracy of the data analysis. GD is the study guarantor.

Funding National Institute of Ageing through the Program on Global Demography of Ageing (PGDA 116508). SSK was supported by the Bernard Lown Scholars in Cardiovascular Health Program. RMZ was supported by an NIH T32 training grant (CA 09001). The sponsors had no influence on the design and conduct of the study; collection, management, analysis and interpretation of the data; and preparation, review or approval of the manuscript.

Disclaimer The lead authors affirm that the manuscript is an honest, accurate and transparent account of the study being reported; that no important aspects of the study have been omitted; and that any discrepancies from the study as planned have been explained.

Competing interests All authors have completed the ICMJE uniform disclosure form at www.icmje.org/coi_disclosure.pdf (available on request from the corresponding author) and declare no support from companies for the submitted work; no relationships with companies that might have an interest in the submitted work in the previous three years; their spouses, partners or children have no 
financial relationships that may be relevant to the submitted work; no non-financial interests that may be relevant to the submitted work.

Ethics approval The study protocol was approved by the Institutional Review Board of the Harvard TH Chan School of Public Health and the Research and Publications Committee of Muhimbili University of Health and Allied Sciences. All participants gave informed consent.

Provenance and peer review Not commissioned; externally peer reviewed. Data sharing statement № additional data available.

Open Access This is an Open Access article distributed in accordance with the Creative Commons Attribution Non Commercial (CC BY-NC 4.0) license, which permits others to distribute, remix, adapt, build upon this work non-commercially, and license their derivative works on different terms, provided the original work is properly cited and the use is non-commercial. See: http://creativecommons.org/ licenses/by-nc/4.0/

(C) Article author(s) (or their employer(s) unless otherwise stated in the text of the article) 2017. All rights reserved. No commercial use is permitted unless otherwise expressly granted.

\section{REFERENCES}

1. Unwin N, Setel P, Rashid S, et al. Noncommunicable diseases in subSaharan Africa: where do they feature in the health research agenda? Bull World Health Organ 2001;79:947-53.

2. Dalal S, Beunza JJ, Volmink J, et al. Non-communicable diseases in sub-Saharan Africa: what we know now. Int J Epidemiol 2011;40:885-901.

3. Mathers CD, Loncar D. Projections of global mortality and burden of disease from 2002 to 2030 [dataset]. Plos Med 2006;3:e442 http:// www.who.int/healthinfo/global_burden_disease/projections/en/index

4. Mathers CD, Stevens GA, Mascarenhas MN. Global health risks: mortality and burden of disease attributable to selected major risks. Geneva, CH: World Health Organization, 2009.

5. Lewington S, Whitlock G, Clarke R, et al. Prospective Studies Collaboration. Blood cholesterol and vascular mortality by age, sex, and blood pressure: a meta-analysis of individual data from 61 prospective studies with 55,000 vascular deaths. Lancet 2007;370:1829-39.

6. Farzadfar F, Finucane MM, Danaei G, et al. National, regional, and global trends in serum total cholesterol since 1980: systematic analysis of health examination surveys and epidemiological studies with 321 country-years and 3.0 million participants. Lancet 2011;377:578-86.

7. Pessinaba S, Mbaye A, Yabeta GA, et al. Prevalence and determinants of hypertension and associated cardiovascular risk factors: data from a population-based, cross-sectional survey in Saint Louis, Senegal. Cardiovasc J Afr 2013;24:180-3.

8. Oluyombo R, Olamoyegun MA, Olaifa O, et al. Cardiovascular risk factors in semi-urban communities in southwest Nigeria: patterns and prevalence. J Epidemiol Glob Health 2015;5:167-74.

9. Asiki G, Murphy GA, Baisley K, et al. Prevalence of dyslipidaemia and associated risk factors in a rural population in South-Western Uganda: a community based survey. PLoS One 2015;10:e0126166.

10. Forouzanfar MH, Alexander L, Anderson HR, et al. GBD 2013 Risk Factors Collaborators. Global, regional, and national comparative risk assessment of 79 behavioural, environmental and occupational, and metabolic risks or clusters of risks in 188 countries, 1990-2013: a systematic analysis for the Global Burden of Disease Study 2013. Lancet 2015;386:2287-323 http://ghdx.healthdata.org/gbd-data-tool

11. Njelekela M, Ikeda K, Mtabaji J, et al. Dietary habits, plasma polyunsaturated fatty acids and selected coronary disease risk factors in Tanzania. East Afr Med J 2005;82:572-8.

12. Njelekela $M$, Sato $T$, Nara $Y$, et al. Nutritional variation and cardiovascular risk factors in Tanzania-rural-urban difference. S Afr Med J 2003;93:295-9.

13. Njelekela M, Kuga S, Nara Y, et al. Prevalence of obesity and dyslipidemia in middle-aged men and women in Tanzania, Africa: relationship with resting energy expenditure and dietary factors. $J$ Nutr Sci Vitaminol 2002;48:352-8.

14. Pauletto P, Puato M, Angeli MT, et al. Blood pressure, serum lipids, and fatty acids in populations on a lake-fish diet or on a vegetarian diet in Tanzania. Lipids 1996;31:S309-12.

15. Marcovina SM, Kennedy H, Bittolo Bon G, et al. Fish intake, independent of apo(a) size, accounts for lower plasma lipoprotein(a) levels in Bantu fishermen of Tanzania: the Lugalawa Study. Arterioscler Thromb Vasc Biol 1999;19:1250-6.
16. Asiki G, Murphy GA, Baisley K, et al. Prevalence of dyslipidaemia and associated risk factors in a rural population in South-Western Uganda: a community based survey. PLoS One 2015;10:e0126166.

17. Shaper AG, Jones KW. Serum-cholesterol, diet, and coronary heartdisease in Africans and Asians in Uganda: 1959. Int J Epidemiol 2012;41:1221-5.

18. Devarajan S, Singh R, Chatterjee B, et al. A blend of sesame oil and rice bran oil lowers blood pressure and improves the lipid profile in mild-to-moderate hypertensive patients. J Clin Lipidol 2016;10:339-49.

19. Huth PJ, Fulgoni VL, Larson BT. A systematic review of high-oleic vegetable oil substitutions for other fats and oils on cardiovascular disease risk factors: implications for novel high-oleic soybean oils. Adv Nutr 2015;6:674-93.

20. Eyres L, Eyres MF, Chisholm A, et al. Coconut oil consumption and cardiovascular risk factors in humans. Nutr Rev 2016;74:267-80.

21. Sun Y, Neelakantan N, Wu Y, et al. Palm Oil Consumption increases LDL Cholesterol compared with Vegetable oils low in Saturated Fat in a Meta-Analysis of clinical trials. J Nutr 2015;145:1549-58.

22. Zatonski W, Campos H, Willett W. Rapid declines in coronary heart disease mortality in Eastern Europe are associated with increased consumption of oils rich in alpha-linolenic acid. Eur J Epidemiol 2008;23:3-10.

23. Kabagambe EK, Baylin A, Ascherio A, et al. The type of oil used for cooking is associated with the risk of nonfatal acute myocardial infarction in costa rica. J Nutr 2005;135:2674-9.

24. Zhang J, Kesteloot $\mathrm{H}$, all-cause Din. Differences in all-cause, cardiovascular and cancer mortality between Hong Kong and Singapore: role of nutrition. Eur J Epidemiol 2001;17:469-77.

25. Bovet P, Romain S, Shamlaye C, et al. Divergent fifteen-year trends in traditional and cardiometabolic risk factors of cardiovascular diseases in the Seychelles. Cardiovasc Diabetol 2009;8:34.

26. Uusitalo U, Feskens EJ, Tuomilehto J, et al. Fall in total cholesterol concentration over five years in association with changes in fatty acid composition of cooking oil in Mauritius: cross sectional survey. BMJ 1996;313:1044-6.

27. Ho O. 2015. Switching to Healthier Fare Just Got Easier for Eateries the Straits Times: Ministry of Communications and Information, Government of Singapore. https://www.gov.sg/ /media/gov/files/ media/20150119_st_switching_to_healthier_fare_just_got_easier_for eateries0f1c.pdf

28. Bovet P, Shamlaye C, Gabriel A, et al. Prevalence of cardiovascular risk factors in a middle-income country and estimated cost of a treatment strategy. BMC Public Health 2006;6:1.

29. Kinabo J, Mnkeni AP, Nyaruhucha CN, et al. Feeding frequency and nutrient content of foods commonly consumed in the Iringa and Morogoro regions in Tanzania. Int J Food Sci Nutr 2006;57(1-2):9-17.

30. Matteucci E, Della Bartola L, Rossi L, et al. Improving CardioCheck PA analytical performance: three-year study. Clin Chem Lab Med 2014;52:1291-6.

31. Ferreira CE, França CN, Correr CJ, et al. Clinical correlation between a point-of-care testing system and laboratory automation for lipid profile. Clin Chim Acta 2015;446:263-6.

32. Njelekela MA, Mpembeni R, Muhihi A, et al. Gender-related differences in the prevalence of cardiovascular disease risk factors and their correlates in urban Tanzania. BMC Cardiovasc Disord 2009;9:30.

33. Lukmanji Z, Hertzmark E, Mlingi N, et al. Tanzania food composition tables [Internet]. Dar es Salaam, TZ: Muhimbili University of Health and Allied Sciences; Tanzania Food and Nutrition Centre; Harvard School of Public Health, 2008. https://www.hsph.harvard.edu/ nutritionsource/food-tables/ (cited 2015 March 15).

34. World Health Organization. Obesity: preventing and managing the global epidemic. Report of a WHO consultation. [Internet]. 894. Geneva, CH: World Health Organization, 2000. http://whqlibdoc. who. int/trs/WHO_TRS_894.pdf (cited 2016 March 18).

35. World Health Organization. Prevention of Noncommunicable Diseases Department. Global Physical activity questionnaire (GPAQ) Analysis Guide [Internet]. Geneva, CH: World Health Organization, 2014:23. http://www.who.int/chp/steps/resources/GPAQ_Analysis_ Guide.pdf (cited 2014 January 07).

36. Filmer D, Pritchett LH. Estimating wealth effects without expenditure data-or tears: an application to educational enrollments in states of India. Demography 2001;38:115-32.

37. Davis RE, Couper MP, Janz NK, et al. Interviewer effects in public health surveys. Health Educ Res 2010;25:14-26.

38. Himelein K. Interviewer effects in subjective survey questions: evidence from Timor-Leste. Int J Public Opin Res 2015; edv031.

39. Njelekela M, Negishi H, Nara Y, et al. Cardiovascular risk factors in Tanzania: a revisit. Acta Trop 2001;79:231-9. 
40. Njelekela MA, Negishi H, Nara $\mathrm{Y}$, et al. Obesity and lipid profiles in middle aged men and women in Tanzania. East Afr Med $J$ 2002;79:58-64.

41. Peer N, Steyn K, Lombard C, et al. Alarming rise in prevalence of atherogenic dyslipidaemia in the black population of Cape Town: the Cardiovascular risk in Black South Africans (CRIBSA) study. Eur J Prev Cardiol 2014;21:1549-56.

42. Doupa D, Seck SM, Dia CA, et al. Dyslipidemia, obesity and other cardiovascular risk factors in the adult population in senegal. Pan Afr Med J 2014;19:181

43. Fornés NS, Martins IS, Hernan M, et al. Food frequency consumption and lipoproteins serum levels in the population of an urban area, Brazil. Rev Saude Publica 2000;34:380-7.

44. Mirmiran P, Noori N, Zavareh MB, et al. Fruit and vegetable consumption and risk factors for cardiovascular disease. Metabolism 2009;58:460-8.

45. Djoussé L, Arnett DK, Coon $\mathrm{H}$, et al. Fruit and vegetable consumption and LDL cholesterol: the national heart, lung, and blood institute family heart study. Am J Clin Nutr 2004;79:213-7.

46. Edem DO. Palm oil: biochemical, physiological, nutritional, hematological and toxicological aspects: a review. Plant Foods Hum Nutr 2002;57(3/4):319-41.

47. Zhao H, Lu Z, Bie X, et al. Analysis of positional distribution of fatty acids in triacylglycerols from lard by high performance liquid chromatography]. Se pu 2005;23:142-5.

48. Hunter JE. Studies on effects of dietary fatty acids as related to their position on triglycerides. Lipids 2001;36:655-68.

49. Service FA. United States Department of Agriculture. Oilseeds: world Markets and Trade [Internet]. Washington, DC: USDA 2017:36 https://apps.fas.usda.gov/psdonline/circulars/oilseeds.pdf (cited 2017 January 13).

50. KPMG BPA Co. Ltd. Potential opportunities for investors [Internet]. Tabora, TZ: KPMG International, 2011:44. http://mci.ei.columbia.edu/ files/2012/12/kpmg-tabora-report.pdf (cited 2016 March 18).
51. Tanzania Data Portal [Internet]Dar es Salaam, TZ: Tanzania National Bureau of Statistics, 2014. http://tanzania.opendataforafrica.org/uelwzeb/ tanzania-fao-stat-water-resources-agriculture-production-and-trade (cited 2016 March 23).

52. Bovet $P$, Viswanathan $B$, Shamlaye $C$, et al. Addressing noncommunicable diseases in the Seychelles: towards a comprehensive plan of action. Glob Health Promot 2010;17:37-40.

53. Dowse GK, Gareeboo H, Alberti KGMM, et al. Changes in population cholesterol concentrations and other cardiovascular risk factor levels after five years of the non-communicable disease intervention programme in Mauritius. BMJ 1995;311:1255-9.

54. Stringhini S, Sinon F, Didon J, et al. Declining Stroke and myocardial infarction mortality between 1989 and 2010 in a country of the african region. Stroke 2012;43:2283-8.

55. Fattore E, Bosetti C, Brighenti F, et al. Palm oil and blood lipidrelated markers of cardiovascular disease: a systematic review and meta-analysis of dietary intervention trials. Am J Clin Nutr 2014;99:1331-50.

56. Weliwita A, Nyange D, Tsujii H. Food demand patterns in Tanzania: a Censored regression analysis of Microdata. Sri Lankan Journal of Agricultural Economics 2011;5.

57. Basu S, Babiarz KS, Ebrahim S, et al. Palm oil Taxes and cardiovascular disease mortality in India: economic-epidemiologic model. BMJ 2013;347:f6048.

58. Wodon QT, Tsimpo C, Backiny-Yetna P, et al. Potential impact of higher food prices on poverty: summary estimates for a dozen west and central African countries [Internet]. 4745. Washington, DC: World Bank, 2008. http://documents.worldbank.org/ (cited 2016 March 18).

59. Wodon QT, Zaman H. Rising food prices in Sub-Saharan Africa: poverty impact and policy responses [Internet. 4738. World Bank: Washington, DC:, 2008. http://documents.worldbank.org/

60. Downs SM, Thow A-M, Ghosh-Jerath S, et al. The feasibility of multisectoral policy options aimed at reducing trans fats and encouraging its replacement with healthier oils in India. Health Policy Plan 2014;czu031. 